Perspective

\title{
Researching Integrated Disaster Risk Management from an Interpretive/Critical Perspective
}

\section{Hamilton Bean ${ }^{1}$}

Received: 15/09/2021 / Accepted: 11/11/2021 / Published online: 28/12/2021

\begin{abstract}
This essay describes what an interpretive/critical perspective on integrated disaster risk management entails and highlights related research contributions in the field. These contributions offer researchers examples of interdisciplinary, international, multimethodological, and cross-cultural research in an array of disaster contexts that reflect the philosophical and normative commitments of interpretive/critical scholarship. The essay describes the author's experiences in applying an interpretive/critical perspective in researching the U.S. Wireless Emergency Alerts (WEA) system, and it explores the value (and risks) that such a perspective holds for policy intervention, institutional practice, and one's own professional development.
\end{abstract}

Keywords: Interpretivism, critical theory, integrated disaster risk management, mobile technology, public alert and warning

\section{RESEARCHING INTEGRATED DISASTER RISK MANAGEMENT FROM AN INTERPRETIVE/CRITICAL PERSPECTIVE}

Drawing from natural sciences, engineering, economics, ecology, and social sciences, integrated disaster risk management considers various natural, technological, and institutional drivers of disaster risk, as well as possible mitigation options including policy, structural, response management, and risk transfer (Wouter Botzen et al., 2019). Much of this work focuses on developing innovative approaches to risk assessment, cost-benefit analysis of risk management options, and ways of optimizing financial, material, technological, and human

\footnotetext{
${ }^{1}$ University of Colorado Denver

* Corresponding author email: HAMILTON.BEAN@ucdenver.edu
} 
resources within and across disaster phases: mitigation, preparedness, response, and recovery. A random scan of recent titles in this journal suggests the scope of related research: "Towards Optimal Architectures for Hazard Monitoring Based on Sensor Networks and Crowdsensing" (Georges, 2020), "Assessment of Social Vulnerability in the Evacuation Process from Mount Merapi: Focusing on People's Behavior and Mutual Assistance" (Chasanah \& Sakakibara, 2020), and "Distributed Ledger Technology for an Improved Index-Based Insurance in Agriculture" (Sushchenko \& Schwarze, 2020), just to name a few.

This type of research is immensely valuable for practitioners and scholars. Yet, consistent with the bulk of disaster risk research, these studies, along with most of the articles in this journal, rely upon an "objectivist" ontology. As Chipangura et al. (2016) state, an objectivist ontology tends to treat disaster risk as an "objective, deductive, nomothetic, quantitative, explanatory and universal" phenomenon (p. 264). This ontological commitment uniquely distinguishes objectivist from interpretive/critical research. Interpretive/critical researchers view social reality as being embedded within and impossible to disassociate from its historical, material, and cultural setting. As a result, interpretive/critical researchers tend to avoid hypothesis testing and instead aim to interpret social reality via in-depth exploration of people's sensemaking processes. This essay introduces an interpretive/critical perspective to disaster risk researchers who may be unfamiliar with its philosophical commitments and objects of study.

The inspiration for this essay is twofold. First, the article, "Theoretical Contributions of Interpretive and Critical Research in Health Communication," written by Heather Zoller and Kimberly Kline, appeared in the Annals of the International Communication Association in 2008. In this essay, I mimic the Zoller and Kline (2008) article in exposing readers to the value (and risks) of an interpretive/critical perspective. Second, this essay coincides with the August 2021 publication of Critical Disaster Studies, edited by Jacob A. C. Remes and Andy Horowitz. That landmark volume introduces readers to a radical idea:

Unlike most existing approaches to disaster, critical disaster studies begins with the idea that disasters are not objective facts, but rather are interpretive fictions - and they shape the way people see the world. By questioning the concept of disaster itself, critical disaster studies reveals the stakes of defining people or places as vulnerable, resilient, or at risk.

This essay likewise argues that many of the concepts deployed within integrated disaster risk management research-i.e., disaster, vulnerability, resilience, risk, and so on-are made meaningful within and through power-laden struggles over language. My hope is that by sharing some of my personal experiences as an interpretive/critical researcher, I might compel some readers to explore what value an interpretive/critical perspective might bring to their research endeavors.

My own work within the integrated disaster risk management area focuses on the moment that lies just between preparedness and response. Specifically, I am among a handful of 
researchers who study mobile public alert and warning (Bean, 2019; Bean et al., 2015; Bopp et al., 2021; Cain et al., 2021; Cao et al, 2021; Casteel \& Downing, 2016; Doermann et al., 2020; Kim et al., 2019; Kuligowski \& Doermann, 2018; Lambropoulos et al., 2021; Ling \& Oppegaard, 2021; Lui et al., 2017; Nakayachi et al., 2019; National Academies of Sciences, Engineering, and Medicine, 2018; Riel, 2019; Sutton \& Kuligowski, 2019; Sutton et al., 2018; Wood et al., 2018; Yoder-Bontrager et al., 2017). Mobile public alert and warning encompasses the technologies, infrastructures, policies, practices, personnel, cognitions, behaviors, and outcomes associated with alert and warning messages delivered through mobile devices (Bean, 2019). I was fortunate to be introduced to this research area by Dr. Dennis S. Mileti when I joined him for a U.S. Department of Homeland Security-funded study of warning system integration in the United States (Bean \& Mileti, 2010). Dr. Mileti was regarded as one of the world's foremost disaster sociologists and a-if not the - principal expert on public alert and warning. Tragically, Dr. Mileti died from complications from COVID-19 in 2021, but his legacy endures.

Even though I was trained in rhetorical and critical-cultural research traditions during my doctoral studies in communication, I have only recently begun to apply an interpretive/critical perspective in my mobile public alert and warning investigations (Bean, 2019; Bean \& Hasinoff, 2022; Bean \& Madden, 2019). My collaborations with Dr. Mileti and colleagues from 2009 to 2016 instead focused on conducting qualitative research of mobile public alert and warning messages in ways that aligned with an objectivist ontology and Dr. Mileti's sociological Hear-Confirm-Understand-Decide-Respond model of public warning (for an overview and critique of this model, see Sellnow \& Seeger, 2013). My doctoral dissertation advisor was Dr. Bryan C. Taylor, co-author of the oft-cited Qualitative Communication Research Methods (Lindlof \& Taylor, 2002), so I felt prepared to address the qualitative research dimensions of the multi-methodological investigation that Dr. Mileti was leading. However, my training under Dr. Taylor emphasized rhetorical and critical-cultural communication research, and I was always slightly uncomfortable about some of the objectivist, linear, and mechanistic assumptions that the Hear-Confirm-Understand-Decide-Respond model made about the nature of communication (see Sellnow \& Seeger, 2013). I did not often discuss these assumptions with Dr. Mileti, although he seemed intrigued about the diversity of communication theory: One time I visited his home in Rancho Mirage, California for a research meeting, and Dr. Mileti delighted in showing me a copy of his first academic publication, which happened to appear in a communication journal. "Who knew I was a communication scholar?" he jibed.

It was in 2017, after being invited by Dr. Keri K. Stephens to the "Crisis \& New Media Conference" at the University of Texas, that I returned to my rhetorical and critical-cultural roots to explore some of the questions that I had ignored during my collaborations with Dr. Mileti. Those explorations culminated in the 2019 volume, Mobile Technology and the Transformation of Public Alert and Warning (Praeger Security International). Although he would not have referred to himself as an interpretive/critical scholar, in engaging "milling" 
behavior in response to warning messages (e.g., Wood et al., 2018), Dr. Mileti was similarly concerned with the messy dynamics of human communication and meaning making.

With this background in mind, in the remainder of this essay, I expand upon Chipangura et al.'s (2016) discussion of social constructivism in disaster risk research. Specifically, drawing from Zoller and Kline (2008), I first describe the commitments of an interpretive/critical perspective. I then highlight recent integrated disaster risk management research that draws upon that perspective. I subsequently discuss the value and risks of the application of that perspective in my own work and conclude with a call for researchers to consider an interpretive/critical perspective in their work.

\section{WHAT IS AN INTERPRETIVE/CRITICAL PERSPECTIVE?}

Similar to its constituent disciplines, integrated disaster risk management research typically entails objectivist or "post-positivist" analysis of economic or cognitive-behavioral variables. Positivism "is based on the belief that there is an objective reality and that knowledge exists as something that can be observed and measured" (Chipangura et al., 2016, p. 263). Postpositivism eschews the (19th century) positivist idea that the researcher and research object (including people) can be completely independent of each other; it instead seeks to avoid hidden biases that subtly taint research preferences and interpretations through improved methodological rigor, triangulation, and error reduction. However, post-positivism maintains an assumption that "the world as it is" can be approximated. Also known as the "correspondence theory" of meaning, this assumption holds that "words" uncomplicatedly denote "things" in the world (Ott \& Domenico, 2015). Take for example the three articles mentioned in the introduction of this essay: Georges (2020) developed mathematical models to address the optimal sensor placement problem. Chasanah and Sakakib (2020) developed an index of people's behavior, mutual assistance, and social vulnerability for pedestrian evacuation. Walking speed and risk perception were the main variables, and mutual assistance was found to be effective in reducing evacuation times for vulnerable people in their case study. Sushchenko and Schwarze (2020) compared features of yield-based insurance and index-based insurance for agriculture to show that an application of distributed ledger technology could solve compensation payment problems and facilitate the development of innovative insurance mechanisms. These post-positivist studies were selected at random, and they offer valuable contributions, but they are typical of the type found in journals that publish integrated disaster risk management research. In these studies, subjective meaning is viewed as transparent or unimportant, i.e., as a neutral link intervening between initiating material factors and the human behaviors those factors are alleged to produce (Blumer, 1969).

By contrast, an interpretivist/critical perspective is drawn from developments in Continental Philosophy that occurred in the second half of the twentieth century. Touchstones within this tradition include the French historian and philosopher Michele Foucault's (2007) investigations 
of how knowledge, discourse, and power reciprocally shape social truths across time. Claude Lévi-Strauss's (2008) development of structural anthropology explained why and how humans are unaware of the workings of the social structures that shape their daily life. Julia Kristeva (1984) examined how "poetic language" challenged correspondence conceptions of meaning in which words merely denoted things or thoughts. These developments greatly contributed to the understanding of the human experience, the relationship between humans, language, and nature, and the arc of social development. These perspectives share a concern for the "intersubjectivity" of language and understanding, that is, the idea that the production and reproduction of knowledge (including self-knowledge) arises from subjective experience shared among people through the exchange of symbols (i.e., language). In the late twentieth century, scholars from across the humanities and social sciences began applying approaches derived from hermeneutics, structuralism, post-structuralism, deconstruction, feminism, psychoanalytic theory, and critical theory in their work. Critical "turns" or variants of anthropology, communication, psychology, and sociology began to emerge to investigate the role of discourse, culture, and power in interpreting social phenomena and shaping disciplinary knowledge.

An interpretive/critical perspective maintains different ontological and epistemological assumptions than a post-positivist perspective. Ontology refers to the nature of phenomena and epistemology refers to how we can study or come to know that nature. Theories, research goals, and practical orientations vary due to different ontological and epistemological assumptions. An interpretive/critical perspective maintains the basic ontological assumption that our perceptions of ourselves and reality are constituted through the meanings that we attach to them. These meanings are historically and culturally constructed through social, power-laden interactions. An interpretive/critical perspective therefore emphasizes meaning's "subjective character, its relational quality, its contextual nature, its non-linguistic dimensions, its embodied tenor, and its indirect referentiality" (Ott \& Domenico, 2015, p. 253). Every human being is born into a set of historical, material, social, and symbolic conditions that they did not choose but which they must confront in making sense of themselves, others, and the physical and social phenomena they experience.

Epistemologically, earthquakes, tsunamis, volcanic eruptions, and other natural phenomena are "non-discursive," but their meanings and implications, like the concepts of "integrated," "disaster," "risk," and "management," are not pregiven and must be constructed and reconstructed intersubjectively. From this perspective, meaning "does not exist prior to utterances; meaning depends upon and emerges within specific language use" (Ott \& Domenico, 2015, p. 245). In other words, what an earthquake "meant" to someone living 500 years ago is not the same as what it means to someone living today due to historical, cultural, and linguistic differences (Steinberg, 2006). Importantly, meaning cannot be separated from processes of disaster risk policy formulation and implementation (Chipangura et al., 2016). Thus, an interpretive/critical perspective focuses squarely on the process of meaning-making. As Zoller and Kline (2008) state: 
This perspective seeks to provide in-depth understanding of lived experience or a unique, well-argued and defended interpretation of a discourse to impart some insight into the multiple ways in which communication fosters particular meanings. Interpretive/critical scholars do not necessarily attend to (in)accuracy or rightness/wrongness of messages as measured against some objective reality. Rather, they engage in the double hermeneutic ... of interpreting others' interpretations, remembering that the phenomena we study in the social sciences are socially constructed. (p. 93)

This perspective nevertheless acknowledges that the meanings humans give to earthquakes, tsunamis, volcanic eruptions, and other natural phenomena are not infinite. Mark Johnson (2013) argued that meaning "arises from the felt qualities of events and situations generated by active and moving bodies ... [it] emerges out of (or originates with) pre-conscious sensorimotor experiences that precede and, subsequently, structure perception and other higher cognitive processes such as intellectual feelings and reflective thinking" (quoted in Ott \& Domenico, 2015, p. 239). Johnson's perspective helps account for the similarity of meanings and practices observed across cultures and time periods in relation to earthquakes, tsunamis, volcanic eruptions, and so on (Garnier, 2019).

The "critical" element in the interpretive/critical perspective relates to the ethical and political position one takes vis-à-vis the double hermeneutic and constructed interpretations. The objective of critical research is not necessarily to defend a scientific consensus or create a new one but rather to provoke "dissensus," i.e., to foster the (sometimes uncomfortable) recognition of the ways that certain people's interests are privileged over other people's interests in the struggle to control meaning (Deetz, 1992). While interpretivism and critical theory both assume socially constructed realities, interpretivism is generally more focused on describing and understanding those realities, while critical theory explicitly seeks to challenge dominant meanings and social orders. A critical perspective emphasizes issues of power, control, inequality, and difference that may be ignored in mainstream disaster risk management research.

The criteria for judging the worth of scholarship differs between a post-positivist and interpretive/critical perspective. Post-positivist studies tend to aim for predictive validity, reliability, and generalizability. An interpretive/critical perspective, by contrast, tends to emphasize the usefulness and depth of insight of a researcher's interpretation through the transparency, comprehensiveness, and quality of the analysis. Evidence within an interpretive/critical study is usually of two types: (a) evidence of a systematic and rigorous analytical process, and (b) evidence of the basis of results and knowledge claims (Greckhamer \& Cilesiz, 2014). The usefulness of the research for both those under study (i.e., in helping to transform inequitable policy and practice) and other discourse communities (i.e., scholars, practitioners, policymakers, etc.) is also a measure of quality. How well a study connects local knowledge to the larger sociocultural context is critical. 
It is important to note that post-positivist and interpretive/critical studies do not necessarily require different methods, although quantitative approaches are typical of the former and qualitative approaches are typical of the latter. Zoller and Kline (2008) observe, however, that "the approach to analyzing and understanding data, not the strategy for collecting data, distinguishes between post-positivist and interpretive/critical research" (p. 95). It is also important to underscore that both generalizability and local specificity can be equally desirable research objectives. Context-dependent findings can generate hypotheses that lead to broad validation and generalization, while generalized findings can, alternately, spur investigations of local, situated knowledge and the diversity of meanings. Post-positivist and interpretive/critical perspectives need not be set in opposition to each other.

That said, an interpretive/critical perspective enables the donning of a particular kind of scholarly identity, one contrasted with alternate ontological and epistemological commitments (e.g., objectivism, post-positivism, experimentalism, etc.). That identity emphasizes the "reflexive study of symbolically-mediated, intersubjective meanings, as they arise experientially" for researchers through their "immediate encounters" with the members of the groups they study (Taylor et al., 2021, p. 5). One's confrontation with that scholarly identity invites reconsideration of the "deep, interconnected questions of what we do, how we do it, and who we are" (p. 2, emphasis in original). Engagement with issues of struggle, trauma, judgement, and advocacy are permitted and encouraged, and avowals of detached, neutral, and de-politicized social-scientific inquiry are viewed with suspicion (Mumby, 1997).

Despite the insights that an interpretive/critical perspective might yield, intellectual communities tend to see some ontological and epistemological perspectives as more legitimate than others based on that community's values and purposes. There is professional risk in using a research perspective that one's peer group does not find legitimate. For some researchers, disaster risk management is a topic exclusively associated with physical and material phenomena that can be objectively assessed, wherein "disaster risk can be viewed as the real, quantifiable product of nature's impact on society; independent from the social constructions of a society" (Chipangura et al., 2016, p. 265). In this regard, integrated disaster risk management research that explicitly applies the philosophical commitments of interpretivism is somewhat rare. Google Scholar reveals just 152 results when using the search terms "disaster risk management" and "interpretivism." Research that draws upon critical theory appears slightly more prevalent, with Google Scholar revealing 250 results when using the search terms "disaster risk management" and "critical theory." There are, of course, plenty examples of research that generally reflect (some of) the commitments of an interpretive/critical perspective without overtly naming it (e.g., Figueroa, 2013; also see Yamori, 2020). Nevertheless, interpretive/critical research is merely a drop in the bucket of integrated disaster risk management research more broadly, which sees 2,300 Google Scholar results using the search term "integrated disaster risk management" and 55,000 results when the word "integrated" is removed.

This section discussed some of the main features of an interpretive/critical perspective. 
The next section highlights how those features have been applied in recent integrated disaster risk management research.

\section{EXAMPLES OF INTEGRATED DISASTER RISK MANAGEMENT RESEARCH USING AN INTERPRETIVE/CRITICAL PERSPECTIVE}

The examples discussed in this section illustrate how researchers have applied an interpretive/critical perspective in disaster risk management studies. This section is not intended as a comprehensive review of scholarship, which is beyond the scope of this essay. In reviewing disaster risk research that uses a social constructivist perspective, Chipangura et al. (2016) already identified and synthesized many interpretive/critical studies. This section therefore concentrates on a handful of post-2015 examples that explicitly invoke an interpretive/critical perspective, as well as the overarching position that:

... disaster risk is not only primarily the outcome of geophysical processes, but can be seen as created in social, economic and political systems, including the product of failed development. Disaster risk is therefore more a function of vulnerability than natural hazards. (Chipangura et al., 2016, p. 268)

For example, Ginige et al. (2016) used an interpretive perspective to examine how to "mainstream" women into disaster reduction practices in the built environment in Sri Lanka (where women accounted for 80 percent of the deaths from the 2004 Indian Ocean earthquake and tsunami). By "mainstreaming," the researchers referred to the process of assessing the implications of any planned disaster reduction action for different gender groups, "It is a strategy for making the concerns and experiences of women as well as men an integral part of the design, implementation, monitoring and evaluation of policies and programmes at all levels to ensure that women and men benefit equally" (p. 612). To do this, the researchers explicitly applied their commitment to the "constructionism ontology and interpretivism epistemology" (p. 612), adopting a case study approach, in-depth interviews, and thematic analysis. Consistent with an interpretive perspective, the researchers acknowledged the contingency of their conclusions and recommendations, "Mainstreaming women into DRR [disaster risk reduction] in the built environment is not a universally standard practice that can be designed to implement in any country or place disregarding the contextual variables such as social, economic, cultural and political factors" (p. 616). Illustrating a critical edge in their analysis, the researchers mined interview data to identify regulatory loopholes that hindered the proper implementation of the gender mainstreaming process. They quoted one of their participants, who warned, "that 'documentation ensuring peoples' voices are heard can be easily manipulated," which suggested that "the process of mainstreaming women could be limited only to a paper exercise" (p. 622). Another participant warned of "people in the local community trying to manipulate DRR knowledge and needs to achieve their personal intentions" (p. 622). In this way, the 
Ginige et al. study represents the critical perspective's focus on power and control over language/text.

The Ginige et al. (2016) study underscores the theme of holding disaster risk management stakeholders accountable for the participatory practices they claim to support. Too often, institutions sustain their power by using the rhetoric and form of community participation yet empty that participation of its substantive content (Doxtader, 1995). For example, in "External Stakeholders' Attitudes Towards and Engagement with Local Knowledge in Disaster Risk Reduction: Are We Only Paying Lip Service?” Trogrlić et al. (2021) demonstrated that "appreciation" of the importance of local knowledge of disaster risk reduction is widespread within the field, but its inclusion in actual practice remains limited (p. 1). Explicitly citing an interpretivist epistemology and using a case study research design, the authors interviewed external stakeholders involved with community-based flood risk management in Malawi to understand the meanings and uses of "local knowledge." They found "the strong dichotomy between local and scientific knowledge persists and it has led to the further marginalisation of [local knowledge]" (p. 1).

From a post-positivist perspective, the idea that disaster risk management experts should give "equal weight, recognition and importance to [local knowledge]" (Trogrlić et al., 2021, p. 1 ) is puzzling. From the traditional perspective, the limits of "local knowledge" actually serve to justify the necessity of disaster risk managers as providers of superior expertise in the first place (Ponce de Leon, 2021). At its worst, disaster risk management research risks stigmatizing local knowledge (read: culture) as a morass of primitive structures and processes contributing to irrational decision-making. An interpretive/critical perspective reconsiders this nonexpert/expert relationship, focusing instead on bi-directional exchange through the collaborative construction of disaster risk information suited to local needs (e.g., Takenouchi et al., 2017). In contrast to a top-down approach, the collaborative paradigm emphasizes that effective disaster risk management practices are collaboratively constructed by collectively transforming a large amount of highly specialized risk information into a format that addresses local needs and the empowerment of local actors (Mărgărint et al., 2021; Takenouchi et al., 2018).

Recent examples of interpretive/critical studies that advance local actor empowerment include Chipangura et al. (2017) and Ponce de Leon (2021). Chipangura et al. (2017) critically explored societal perceptions of disaster risk problems in Zimbabwe in order to give them meaning and render them manageable. The researchers found that similar to the case in other non-Western countries, Zimbabwe's disaster risk management system is dominated by the "hazard frame," with rival frames such as "vulnerability" and "theistic" being silenced (p. 317). The researchers' interpretive/critical analysis concluded:

... disaster risk problems should not be viewed as unitary and state-centred, but rather as diverse and multi-dimensional. This realisation is crucial in understanding that the locus of disaster risk problem is not to be found primarily in governmental agencies; 
rather, it is to be found in the communities where risk is generated and experienced. (p. 323)

In "The Purok System of San Francisco, Camotes: A Communication Perspective of Community-Based Haiyan Response," Ponce de Leon (2021) similarly argued that the community-based disaster risk management (CBDRM)-based purok system used in the Philippines is superior to the top-down approach to disaster risk management imposed by national authorities. However, Ponce de Leon's analysis did not simply valorize local knowledge: it acknowledged that the purok system has at times not worked well because communities have lacked trust in their local government leaders. Ponce de Leon stated that despite the promise of empowerment, "the purok system is largely top down in its transfer of knowledge: citizens feel that the purok system forces them to volunteer, obey, and cooperate on penalty of not being helped in the future" (p. 3). Ponce de Leon's critical analysis demonstrates how the move from top-down to horizontal and collaborative approaches is not immune to the influence of power. As Fuentealba et al. (2020) state:

Although the literature asserts that DRR - like all policy interventions - is a political process, there is still a need to expand this knowledge in terms of how DRR governance evolves over time and how and when policy implementation produces certain effects on the ground. (p. 245)

An interpretive/critical perspective does not shy away from the power-laden dynamics of disaster risk management, i.e., its institutional and disciplinary politics. The next section further engages these themes.

\section{APPLYING AN INTERPRETIVE/CRITICAL PERSPECTIVE IN MOBILE PUBLIC ALERT AND WARNING RESEARCH}

In this section, I discuss how I have applied an interpretive/critical perspective in my research concerning mobile public alert and warning, and I describe the value (and risks) that such a perspective holds for policy intervention, institutional practice, and researchers' professional development. As the studies reviewed above indicate, there is no singular approach to applying an interpretive/critical perspective, and within my own research, I have drawn upon grounded theory, rhetorical analysis, cultural studies, and ideology critique in analyzing and interpreting mobile public alert and warning phenomena.

For example, before experts can "optimize" mobile alert and warning messages (National Academies, 2018), they must understand how diverse groups of people make sense of and respond to their content. During my collaborations with Dr. Mileti, I used a grounded approach (Strauss \& Corbin, 1997) to identify and analyze themes that emerged from focus groups I conducted with community members in Denver, Colorado. I discussed with these community members mock WEA messages for different types of hazards. While the themes that emerged 
were viewed through an objectivist lens and associated with Dr. Mileti's Hear-ConfirmUnderstand-Decide-Respond model of public warning (Bean et al., 2014), the experience was nevertheless eye-opening in helping me see how race, class, and gender intersected people's interpretations and responses (social categories were not the focus of the project, however). For example, a few of the Black participants in the focus groups commented that messages emanating from the Denver Police Department would not be trusted, while nearly every White participant voiced high levels of trust in those messages (Bean et al., 2014). The project did not test mock messages in Spanish, thereby further entrenching what de Onís et al. (2020) have called emergency management's "English monolingualism." When asking participants about the messages' instruction to shelter in a basement, some participants intimated that they had no basement, revealing the message writer's middle-class assumptions about the typical domicile (Bean et al., 2014). Several women in the focus groups stressed their responsibilities as mothers: They would seek to protect their children before all else, even in ways that could seem irrational.

In this case, an interpretive/critical perspective was valuable for surfacing differences in what constitutes an "appropriate" response to mobile alert and warning messages. The perspective usefully accounts for the diverse experiences of research participants. While I did not conduct contextualized investigation of alert and warning response based on social identity categories, I gained an awareness of how "non-rational" ways of responding to warning messages are construed based upon a particular set of values and assumptions. In subsequent studies, I have taken to heart the lessons learned from this experience, striving to ensure that research designs better account for participants' demographic, linguistic, and cultural diversity. Public alert and warning officials must likewise account for their community members' diverse experiences despite what generalized (post-positivist) social science research findings may reveal.

Another area where an interpretive/critical perspective has been valuable is in understanding how technological choices shape mobile public alert and warning policies and practices. Traditional risk communication studies typically correlate alert and warning message elements with public responses (e.g., Sutton et al., 2018). While such studies are extremely valuable, knowledge, discourse, and power embedded within institutional settings shape technological choices in the first place. In my study of the origin and design of the WEA system (Bean, 2019), I used an interpretive/critical perspective and a rhetorical approach to analyze how certain stakeholders framed the "problem" that the WEA system was supposed to address. These stakeholders defined the problem in terms of the need for a "bell ringer," i.e., a mobile devicebased alert that would compel recipients to check other sources of media (e.g., television or radio) for further information. Other stakeholders, however, believed that the "bell ringer" framing discounted the powerful role that mobile devices could play in helping message recipients immediately obtain additional and confirming information. These stakeholders instead sought to shape the WEA system in ways that facilitated rapid information acquisition via messages that included hyperlinks and phone numbers. Several years after the initial design of the WEA system had been approved (without permitting embedded hyperlinks and phone 
numbers), the U.S. Federal Communications Commission (FCC) reversed course, claiming that wireless service providers had provided no evidence that such inclusions would degrade their networks, as had been asserted during the WEA system design phase (see Bean, 2019).

In this case, we can observe how certain stakeholders sought to control discourse in ways that produced outcomes congruent with their material (read: financial) interests. It took 12 years for the design of the WEA system to change, illustrating how the struggle to control meaning can produce lasting consequences for disaster risk management technologies and those who must use them. Integrated disaster risk management researchers would do well to scrutinize how certain assumptions, policies, and processes are constructed as "normal," "natural," or "self-evident" within institutional settings. A critical perspective might emphasize, for example: a) how historical/social processes construct the authority, legitimacy, and standard operating procedures of disaster risk managers (e.g., de Onís et al., 2020); b) how disaster risk management discourses work to suppress or elide conflict among competing groups (Bean, 2019); c) how techno-rationality prohibits indigenous or alternative reasoning and decisionmaking processes (e.g., Ponce de Leon, 2021); and d) how instrumental rationality and technocratic authority compel consent from stakeholders (e.g., Shaw et al., 2021). A critical perspective calls for the undistorted representation of the full variety of stakeholder voices in processes of disaster risk management decision-making (Deetz, 1992).

Lastly, an interpretive/critical perspective has been valuable in investigating the role of institutional ideology and identity vis-à-vis WEA system policies and practices. Specifically, I have critiqued the WEA system's "Presidential Alert" message class, demonstrating how it perpetuates ideological assumptions about the necessity of presidential control during a national emergency (Bean, 2019). The design of the WEA system is shot through with the Cold War-era assumption that instantaneous presidential communication is not only desirable but the principal reason to have a national alert and warning system in the first place (Siegel, 2011). The problem with this assumption is that many Americans do not share institutional members' belief that the President of the United States should be always able to (under all conditions) send a message to them. For example, the FCC acknowledges that a Presidential Alert could interrupt the last goodbyes exchanged between loved ones during a cataclysmic disaster (such as a nuclear attack). The occupational identities and ideological commitments of those in control of the WEA system have naturalized presidential authority and control as institutionalized "common sense." The Presidential Alert moniker reinforces a technocratic, "closed world" ideology (Edwards, 1996).

In 2021, following a 2018 false alert WEA message of a nuclear missile attack on Hawaii, the FCC cited comments based on my interpretive/critical research (Bean, 2019) in a rulemaking that renamed the Presidential Alert message class as "National Alert" to avoid undesirable political associations that could hamper public protective action compliance (Federal Communications Commission, 2021). In this case, an interpretive/critical perspective helps us see how policy making is marked by complex interactions among rhetoric, ideology, and identity. An interpretive/critical perspective reveals the "gaps, compulsions, excesses, 
contradictions, absurdities, and repressions of hegemonic ideology" (Taylor, 2010, p. 7). Indeed, even Dr. Mileti once mocked the peculiar deference paid to the WEA system's Presidential Alert message class:

No words out of a president's mouth after a nuclear attack are going to calm anybody.

If we just had ten nuclear bombs take out Chicago, New York City, Washington,

D.C., Los Angeles, Seattle, Houston, Dallas, etc., do you think it's going to be

possible to calm anxious nerves? It's insanity. (Every Little Thing, 2017, 20: 48)

These examples point to the value of an interpretive/critical perspective, but there is professional risk involved in challenging dominant perspectives. Let me be blunt: Interpretive/critical researchers risk being excluded from institutional funding opportunities that privilege mainstream approaches. Institutional elites may shun one's work, denying interpretive/critical researchers both access to inside arenas of decision-making and the ability to participate in related initiatives, working groups, or conferences. Disciplinary colleagues may deem one's work "renegade" and avoid collaborations. Similar to the challenges faced by "activist" researchers (Frey \& Carragee, 2007), those who deploy an interpretive/critical perspective in their work may confront a more difficult career path. The payoff for using an interpretive/critical perspective, however, is considerable: intellectual sanction to (a) investigate processes of meaning construction, (b) explore knowledge of disaster risk management practices and everyday experiences, (c) theorize the politics of identity construction and its relationship to social power in disaster risk management, and (d) amplify marginalized voices (Zoller \& Kline, 2008). For me, the benefits have so far been worth the risks, but every researcher must calculate for themselves the potential tradeoffs.

\section{CONCLUSION}

Interpretive/critical research has made major contributions in disaster-related fields including health communication, sociology, psychology, and others. Work directly within the integrated disaster risk management arena cited herein is promising, and we can expect more to follow in the future. Organizations such as New York University's Initiative for Critical Disaster Studies signal that disaster risk reduction, disaster medicine, public health, emergency management, and various engineering fields are ripe of the application of an interpretive/critical perspective. Indeed, the IDRiM Society's charter states that its main objective is to "promote knowledge sharing, interdisciplinary research and development on integrated disaster risk management contributing to the implementation of success models for efficient and equitable disaster risk management options" (2021). The IDRiM Society's acknowledgment of "equity" is laudable. An interpretive/critical perspective likewise emphasizes that research should aim to cultivate marginalized voices, to support people who are most at risk, and to contribute to efforts to build more just, equitable, and safe communities. 
Finally, this reflection essay is itself a construction and interpretation. It works to define disciplinary boundaries and shape meaning. It aims to challenge certain disciplinary norms but may also reify others. It represents one researcher's attempt to make sense of his life's experiences and to impart something of value to readers. It asks readers to critically assess whose voices are being heard and whose interests are being served in disaster-related research and to reflect upon how the pursuit of (post-positivist) theory development intersects the lived experience of those who must confront the onset or aftermath of a disaster, as well as those who study such groups. Ideally, this essay might serve as a resource to either shake up takenfor-granted assumptions about the nature and role of research or bolster one's resolve in choosing an interpretive/critical perspective. Interpretive/critical research may not always be well received by colleagues and stakeholders who may have more to gain by ignoring the substance of its ethical and political implications. Asking questions about power, control, interests, and equity can spur discomfort, suspicion, or resentment. But it can also inspire, critique, and cajole — and those outcomes are at the heart of the scientific enterprise as much as any other.

\section{REFERENCES}

Bean, H. (2019) Mobile technology and the transformation of public alert and warning. Santa Barbara, CA: Praeger.

Bean, H., and Hasinoff, A. A. (2022) The social functions of idle alerts. In L. Austin, \& Y. Jin (Eds.), Social media and crisis communication, 2nd ed. Routledge, New York.

Bean, H., and Madden, S. (2019) Mobile crisis communication: Temporality, rhetoric, and the case of Wireless Emergency Alerts. In K. K. Stephens (Ed.), New media in times of crisis, New York: Routledge, pp. 126-143.

Bean, H., and Mileti, D. (2010) Warning system integration research final report. FEMA/ National Consortium for the Study of Terrorism and Responses to Terrorism, College Park, MD. https://start.umd.edu/pubs/START_RCPGPWarningSystemIntegrationResear chProject_Nov2010.pdf

Bean, H., Liu, B., Madden, S., Mileti, D., Sutton, J., and Wood, M. (2014) Comprehensive testing of imminent threat public messages for mobile devices. College Park: National Consortium for the Study of Terrorism and Responses to Terrorism. https://www.dhs.gov/publication/wea-comprehensive-testing-imminent-threat-publicmessages-mobile-devices-updated

Bean, H., Sutton, J., Liu, B. F., Madden, S., Wood, M. M., and Mileti, D. S. (2015) The study of mobile public warning messages: A research review and agenda. Review of Communication, 15 (1): 60-80. https://doi.org/10.1080/15358593.2015.1014402

Blumer, H. (1969). Symbolic interactionism: Perspective and method. Berkeley, CA: University of California Press.

Bopp, E., Gisclard, B., Douvinet, J., Weiss, K., and Martin, G. (2021) How to improve alert systems: The technical, human, environmental and structural aspects. Australian Journal of Emergency Management, 36 (1): 67-75. https://search.informit.org/doi/abs/10.3316/ag ispt.20210525047171 
Cain, L., Herovic, E., and Wombacher, K. (2021) "“You are here': Assessing the inclusion of maps in a campus emergency alert system. Journal of Contingencies and Crisis Management, 29 (3): 332-340. Advance online publication. https://doi.org/10.1111/14685973.12358

Cao, Y., Zhang, N., Zhang, X., and Zhang, J. (2021) Warning dissemination and public response in China's new warning system: Evidence from a strong convective event in Qingdao City. Journal of Risk Research. Advance online publication. https://doi.org/10.1080/13669877.2021.1905694

Casteel, M. A., and Downing, J. R. (2016) Assessing risk following a wireless emergency alert: Are 90 characters enough? Journal of Homeland Security and Emergency Management, 13 (1): 95-112. https://doi.org/10.1515/jhsem-2015-0024

Chasanah, F., and Sakakibara, H. (2021) Assessment of social vulnerability in the evacuation process from Mount Merapi: Focusing on people's behavior and mutual assistance. Integrated Disaster Risk Management Journal, $10 \quad$ (2): 15-34. https://doi.org/10.5595/001c.21409

Chipangura, P., Van Niekerk, D., and Van Der Waldt, G. (2017) Disaster risk problem framing: Insights from societal perceptions in Zimbabwe. International Journal of Disaster Risk Reduction, 22: 317-324. https://doi.org/10.1016/j.ijdrr.2017.02.012

Chipangura, P., Van Niekerk, D., and Van Der Waldt, G. (2016) An exploration of objectivism and social constructivism within the context of disaster risk. Disaster Prevention and Management, 25 (2): 261-274. https://doi.org/10.1108/DPM-09-2015-0210

Deetz, S. A. (1992). Democracy in an age of corporate colonization: Developments in communication and the politics of everyday life. Albany, NY: State University of New York Press.

Doermann, J.L., Kuligowski, E.D., and Milke, J., 2020 "From social science research to engineering practice: Development of a short message creation tool for wildfire emergencies." Fire Technology, 1-23. https://doi.org/10.1007/s10694-020-01008-7

Doxtader, E. (1995) Learning public deliberation through the critique of institutional argument. Argumentation and Advocacy, 31 (4): 185-203. https://doi.org/10.1080/ 00028533.1995 .11951610

Edwards, P. N. (1996) The closed world: Computers and the politics of discourse in Cold War America. Cambridge, MA: MIT Press.

Every Little Thing. (2017, May 22) This is an activation [Audio podcast episode].https://www.gimletmedia.com/every-little-thing/this-is-an-activation

Federal Communications Commission. (2021) FCC further strengthens emergency alerting. https://www.fcc.gov/document/fcc-further-strengthens-emergency-alerting-0

Figueroa, P. M. (2013) Risk communication surrounding the Fukushima nuclear disaster: An anthropological approach. Asia Europe Journal, 11 (1): 53-64. https://doi.org/10.1007/s10308-013-0343-9

Foucault, M. (2007) Discipline and punish: The birth of the prison. Durham, NC: Duke University Press.

Frey, L. R., and Carragee, K. (Eds.) (2007) Communication activism: Vol. 1, communication for social change. Cresskill, NJ: Hampton. 
Fuentealba, R., Verrest, H., \& Gupta, J. (2020) Planning for exclusion: The politics of urban disaster governance. Politics and Governance, 8 (4): 244-255. https://doi.org/10.17645/pag.v8i4.3085

Garnier, E. (2019) Lessons learned from the past for better resilience to contemporary risks. Disaster Prevention and Management, $28 \quad$ (6): 786-803. https://doi.org/10.1108/DPM-09-2019-0303

Georges, D. (2020). Towards optimal architectures for hazard monitoring based on sensor networks and crowdsensing. Integrated Disaster Risk Management Journal, 10 (1): 104-146. https://doi.org/10.5595/001c.17963

Ginige, K., Amaratunga, D., and Haigh, R. (2016) Mainstreaming women into disaster reduction in the built environment. Disaster Prevention and Management, 25 (5): 611-627. https://doi.org/10.1108/DPM-11-2015-0255

Greckhamer, T., \& Cilesiz, S. (2014) Rigor, transparency, evidence, and representation in discourse analysis: Challenges and recommendations. International Journal of Qualitative Methods, 13 (1): 422-443. https://doi.org/10.1177/160940691401300123

IDRiM Society. (2021) Charter and bylaws. https://idrim.org/?page_id=20

Johnson, M. (2013) The body in the mind: The bodily basis of meaning, imagination, and reason. Chicago: University of Chicago Press.

Kim, G., Martel, A., Eisenman, D., Prelip, M., Arevian, A., Johnson, K. L., and Glik, D. (2019) Wireless Emergency Alert messages: Influences on protective action behaviour. Journal of Contingencies and Crisis Management, 27 (4): 374-386. https://doi.org/10.1111/14685973.12278

Kristeva, J. (1984) Revolution in poetic language. New York: Columbia University Press.

Kuligowski, E. D., and Doermann, J. (2018) A review of public response to short message alerts under imminent threat. Washington, DC: US Department of Commerce, National Institute of Standards and Technology. https://nvlpubs.nist.gov/nistpubs/Technical Notes/NIST.TN.1982.pdf

Lambropoulos, D., Yousefvand, M., \& Mandayam, N. (2021) Tale of seven alerts: Enhancing Wireless Emergency Alerts (WEAs) to reduce cellular network usage during disasters.arXiv.org. https://arxiv.org/pdf/2102.00589.pdf

Lévi-Strauss, C. (2008) Structural anthropology. Basic Books, New York.

Lindlof, T. R., \& Taylor, B. C. (2002) Qualitative communication research methods. Thousand Oaks. Sage publications, CA.

Ling, R., \& Oppegaard, B. (2021) THIS IS NOT A DRILL: Mobile telephony, information verification, and expressive communication during Hawaii's false missile alert. Social Media + Society, 7 (1), Advance online publication. https://doi.org/10.1177/2056305121999661

Liu, B. F., Wood, M. M., Egnoto, M., Bean, H., Sutton, J., Mileti, D., \& Madden, S. (2017) Is a picture worth a thousand words? The effects of maps and warning messages on how publics respond to disaster information. Public Relations Review, 43 (3): 493-506. https://doi.org/10.1016/j.pubrev.2017.04.004

Mărgărint, M. C., Niculiţă, M., Roder, G., \& Tarolli, P. (2021) Risk perception of local stakeholders on natural hazards: Implications for theory and practice. Natural Hazards and Earth System Sciences Discussions, 1-45. https://doi.org/10.5194/nhess-2021-37 
Mumby, D. K. (1997) Modernism, postmodernism, and communication studies: A rereading of an ongoing debate. Communication Theory, 7 (1): 1-28. https://doi.org/10.1111/j.14682885.1997.tb00140.x

Nakayachi, K., Becker, J. S., Potter, S. H., \& Dixon, M. (2019) Residents' reactions to earthquake early warnings in Japan. Risk Analysis, 39 (8): 1723-1740. https://doi.org/10.1111/risa.13306

National Academies of Sciences, Engineering, and Medicine. (2018) Emergency alert and warning systems: current knowledge and future research directions. Washington, DC: The National Academies Press. https://www.nap.edu/catalog/24935/emergency-alert-andwarning-systems-current-knowledge-and-future-research

de Onís, C. M., Cubelos, E., \& Chavarria, M. D. R. O. (2021) "No había humanidad": Critiquing English monolingualism and other entwined systems of white supremacy in local emergency management responses. Social Justice, 47 (1-2): 135-170. http://www.socialjusticejournal.org/wp-content/uploads/2021/05/159_06_de-Onis.pdf

Ott, B. L., \& Domenico, M. (2015) Conceptualizing meaning in communication studies. In P. J. Gehrke \& W. M. Keith (Eds.). A century of communication studies: The unfinished conversation. Routledge, New York, pp. 234-260.

Ponce de Leon, I. Z. (2021) The purok system of San Francisco, Camotes: A communication perspective of community-based Haiyan response. International Journal of Disaster Risk Reduction, 102379. https://doi.org/10.1016/j.ijdrr.2021.102379

Remes, J. A. C., \& Horowitz, A. (Eds.) (2021) Critical disaster studies. Philadelphia, PA: University of Pennsylvania Press.

Riel, Z. J. J. (2019). Response to a WEA tornado warning text message (Doctoral dissertation, Western Illinois University).

Sellnow, T. L., \& Seeger, M. W. (2013) Theorizing crisis communication (Vol. 4). John Wiley $\&$ Sons, New York.

Siegel, G. (2011) Radiating emergency: The perils and promise of the broadcast signal in the atomic age. Communication and Critical/Cultural Studies, 8 (3): 286-306. https://doi.org/10.1080/14791420.2011.594069

Strauss, A., \& Corbin, J. M. (1997) Grounded theory in practice. Thousand Oaks, Sage Publications, CA.

Sutton, J. and Kuligowski, E.D. (2019) Alerts and warnings on short messaging channels: Guidance from an expert panel process. Natural Hazards Review, 20 (2), 04019002. https://doi.org/10.1061/(ASCE)NH.1527-6996.0000324

Sutton, J., Vos, S. C., Wood, M. M., and Turner, M. 2018. "Designing effective tsunami messages: Examining the role of short messages and fear in warning response." Weather, Climate, and Society, 10 (1): 75-87. https://doi.org/10.1175/WCAS-D-17-0032.1

Shaw, R., Pulhin, J. M., \& Inoue, M. (2021) Disaster risk reduction, climate change adaptation, and human security: A historical perspective under the Hyogo framework and beyond. In J. M. Pulhin, M. Inoue \& R. Shaw (eds), Climate change, disaster risks, and human security: Asian experience and perspectives. Springer, New York, pp. 21-36.

Steinberg, T. (2006) Acts of God: The unnatural history of natural disaster in America. Oxford: Oxford University Press. 
Sushchenko, O., \& Schwarze, R. (2021) Distributed ledger technology for an improved indexbased insurance in agriculture. Integrated Disaster Risk Management Journal, 10 (2): 6685. https://doi.org/10.5595/001c.21955

Sutton, J., Vos, S. C., Wood, M. M., \& Turner, M. (2018) Designing effective tsunami messages: Examining the role of short messages and fear in warning response. Weather, Climate, and Society, 10 (1): 75-87. https://doi.org/10.1175/WCAS-D-17-0032.1

Takenouchi, K., Nakanishi, C., Yamori, K., Sawada, M., Takeuchi, K., \& Fujiwara, H. (2018) Collaborative Community Weather Information for meteorological disasters: A case study of Nakajima SchoFol District, Ise. Integrated Disaster Risk Management Journal, 7 (2), 1-24. https://www.idrimjournal.com/article/11668.pdf

Taylor, B. C. (2010) Don't mess with Mr. In-Between: Discourses of masculinity in the postCold War era. Presented to the Cold War Cultures Conference, University of Texas-Austin.

Taylor, B. C., Barley, W. C., Brummans, B. H. J. M., Ellingson, L. L., Ganesh, S., Herrmann, A. F., Rice, R. M., Tracy, S. J. (2021) Revisiting ethnography in organizational communication studies. Management Communications Quarterly [Online First]. https://doi.org/10.1177/08933189211026700

Trogrlić, R. Š., Duncan, M., Wright, G., van den Homberg, M., Adeloye, A., Mwale, F., \& McQuistan, C. (2021) External stakeholders' attitudes towards and engagement with local knowledge in disaster risk reduction: Are we only paying lip service? International Journal of Disaster Risk Reduction, 58, 102196. https://doi.org/10.1016/j.ijdrr.2021.102196

Wood, M. M., Mileti, D. S., Bean, H., Liu, B. F., Sutton, J., \& Madden, S. (2018) Milling and public warnings. Environment and Behavior, 50 (5): 535-566. https://doi.org/10.1177/0013916517709561

Wouter Botzen, W. J. et al. (2019) Integrated disaster risk management and adaptation. In R. Mechler, L. Bouwer, T. Schinko, S. Surminski \& J. Linnerooth-Bayer (eds), Loss and damage from climate change: Concepts, methods and policy options. Springer, New York, pp. 287-316. https://doi.org/10.1007/978-3-319-72026-5_12

Yamori, K. (Ed.) (2020) Disaster risk communication: A challenge from a social psychological perspective. Singapore: Springer Singapore.

Yoder-Bontrager, D., Trainor, J. E., \& Swenson, M. (2017) Giving attention: Reflections on severe weather warnings and alerts on mobile devices. International Journal of Mass Emergencies \& Disasters, 35 (3). http://ijmed.org/articles/732/

Zoller, H. M., \& Kline, K. N. (2008) Theoretical contributions of interpretive and critical research in health communication. Annals of the International Communication Association, 32 (1): 89-135. https://doi.org/10.1080/23808985.2008.11679076 